\title{
Age-related changes to vascular protease-activated receptor 2 in metabolic syndrome: A relationship between oxidative stress, receptor expression and endothelium- dependent vasodilation.
}

\begin{tabular}{|r|l|}
\hline Journal: & Canadian Journal of Physiology and Pharmacology \\
\hline Manuscript ID & cjpp-2016-0298.R2 \\
\hline Manuscript Type: & Article \\
\hline Domplete List of Authors: & $\begin{array}{l}\text { Maruyama, Kana; Department of Pharmacology, School of Pharmacy and } \\
\text { Pharmaceutical Sciences, Mukogawa Women's University } \\
\text { Kagota, Satomi; Department of Pharmacology, School of Pharmacy and } \\
\text { Pharmaceutical Sciences, Mukogawa Women's Univers, } \\
\text { McGuire, John; Division of Basic Medical Sciences } \\
\text { Wakuda, Hirokazu; Department of Pharmacology, School of Pharmacy and } \\
\text { Pharmaceutical Sciences, Mukogawa Women's University } \\
\text { Yoshikawa, Noriko; Department of Pharmacology, School of Pharmacy and } \\
\text { Pharmaceutical Sciences, Mukogawa Women's University } \\
\text { Nakamura, Kazuki; Department of Pharmacology, School of Pharmacy and } \\
\text { Pharmaceutical Sciences, Mukogawa Women\'s Univers } \\
\text { Shinozuka, Kazumasa; Department of Pharmacology, School of Pharmacy } \\
\text { and Pharmaceutical Sciences, Mukogawa Women's University }\end{array}$ \\
\hline Keyword: & $\begin{array}{l}\text { protease-activated receptor 2, receptor expression, endothelium- } \\
\text { dependent vasodilation, metabolic syndrome, oxidative stress }\end{array}$ \\
\hline
\end{tabular}

\section{SCHOLARONE \\ Manuscripts}


Age-related changes to vascular protease-activated receptor 2 in metabolic syndrome: A relationship between oxidative stress, receptor expression and endothelium-dependent vasodilation.

Kana Maruyama ${ }^{1}$, Satomi Kagota $\mathrm{PhD}^{1}$, John J. McGuire $\mathrm{PhD}^{2}$, Hirokazu Wakuda $\mathrm{PhD}^{1}$, Noriko Yoshikawa $\mathrm{PhD}^{1}$, Kazuki Nakamura $\mathrm{PhD}^{1}$, Kazumasa Shinozuka $\mathrm{PhD}^{1}$

${ }^{1}$ Department of Pharmacology, School of Pharmacy and Pharmaceutical Sciences, Mukogawa Women’s University, 11-68 Koshien Kyuban-cho, Nishinomiya 663-8179, Japan.

${ }^{2}$ Cardiovascular Research Group, Division of BioMedical Sciences, Faculty of Medicine, Memorial University, 300 Prince Philip Drive, St. John's, Newfoundland, Canada, A1B 3V6.

Address for Correspondence: Satomi Kagota, Ph.D.

Department of Pharmacology II, School of Pharmaceutical Sciences, Mukogawa Women's University

11-68 Koshien Kyuban-cho, Nishinomiya 663-8179, Japan

E-mail: skagota@mukogawa-u.ac.jp; TEL\&FAX: +81-798-45-9944 
Abstract (199/200 words)

Protease-activated receptor 2 (PAR2) is expressed in vascular endothelium. Nitric oxide (NO)-cyclic GMP mediated vasodilation in response to 2-furoyl-LIGRLO-amide (2fLIGRLO), a PAR2-activating peptide, is impaired in aortas from aged SHRSP.Z-Lepra ${ }^{\text {a }} / \mathrm{IzmDmcr}$ rats (SHRSP.ZF) with metabolic syndrome. Here we investigated mechanisms linking PAR2's vascular effects to phenotypic characteristics of male SHRSP.ZF at 10, 20 and 30 weeks of age. We found vasodilation responses to either 2 fLIGRLO or enzyme-mediated PAR2 activation by trypsin were sustained until 20 -weeks and were less at 30-weeks. PAR2 protein and mRNA levels were less in aortas at 30 than at 10 and 20 weeks. PAR2-mediated responses positively correlated with PAR2 protein and mRNA levels. Decreased cGMP accumulation treated with 2fLIGRLO paralleled the decreased relaxations elicited by nitroprusside and the cGMP-analog 8-pCPT-cGMP, and less soluble guanylyl cyclase protein at 30-weeks. 2fLIGRLO-induced relaxation was negatively correlated with serum thiobarbituric acid reactive substances, an index of oxidative stress, which increased with age. Forward-stepwise data regression supported a model of age-related decreases in PAR2 function resulting from decreased PAR2 mRNA and increased oxidative stress. We conclude that decreased responsiveness of aortic smooth muscle 
to NO and downregulation of receptor expression impair PAR2 functions at later stages of metabolic syndrome in SHRSP.ZF.

Keywords: protease-activated receptor 2, receptor expression, endothelium-dependent vasodilation, metabolic syndrome, oxidative stress 
Introduction (497/500words)

Metabolic syndrome is characterized as visceral obesity, hypertension, insulin resistance and hyperlipidemia. People with metabolic syndrome are at increased risk of developing cardiovascular disease compared with those without the syndrome (Hanson et al. 2002; Lakka et al. 2002). The SHRSP.Z-Lepr ${ }^{/ a} /$ IzmDmcr rat (SHRSP.ZF) is an animal model of metabolic syndrome established from a breeding program with stroke-prone spontaneously hypertensive rats and Zucker Fatty rats (Hiraoka-Yamamoto et al. 2004). SHRSP.ZF exhibit obesity, hypertension, and metabolic abnormalities, similar to those found in patients with metabolic syndrome. SHRSP.ZF also show dysfunctional responses in their vasculature. We reported that nitric oxide (NO)-mediated vasodilation in response to acetylcholine and nitroprusside in aortas, mesenteric arteries, and coronary arteries of SHRSP.ZF is impaired by a decrease in soluble guanylyl cyclase (sGC), a receptor protein of NO in smooth muscle (Kagota et al. 2010; Kagota et al. 2013). Interestingly, under conditions of the impaired NO response, vasodilation in response to protease-activated receptor 2 (PAR2) is preserved in aortas and mesenteric arteries from SHRSP.ZF (Kagota et al. 2014; Maruyama et al. 2016). 
Interest in PAR2 as a target for drugs to treat chronic inflammation and metabolic dysfunction conditions, including diabetes, obesity, and metabolic syndrome, is growing (reviewed in Kagota et al. 2016). PAR2 is expressed by the vascular endothelium, as well as other cells such as adipocytes. PAR2 is activated by serine proteases, including trypsin, human mast cell beta-tryptase, human kallikrein isoforms, and coagulation factors VIIa and Xa (Adams et al. 2011; Steinhoff et al. 2005; Yau et al. 2013). PAR2 activation is proposed to be an important contributor to inflammatory pathological conditions (Bucci et al. 2005; Samad and Ruf 2013). Under diabetic and metabolic syndrome conditions, PAR2-activating peptide-induced vasodilation is preserved in mesenteric arteries from B6.BKS(D)-Lepr ${ }^{\text {tb }} / \mathrm{J}(\mathrm{db} / \mathrm{db})$ mice with type 2 diabetes at 12 weeks of age (wks) (Kagota et al. 2011). In contrast, under hypertensive or diabetic conditions, the vasodilation is enhanced in aortas from spontaneously hypertensive rats (SHR) at 9-11 wks (Aman et al. 2010), in coronary arteries from db/db mice at 12-16 wks (Park et al. 2011) and in mesenteric arteries from Goto-Kakizaki rats at 32-40 wks (Matsumoto et al. 2009). Metabolic syndrome is a chronic condition with clinical complications that increase with the period of disease and the age of the individual. Only a few studies have investigated whether 
PAR2-mediated vasorelaxation is progressively altered during the disease period (Kagota et al.

2016). One of these reports indicates that enhanced PAR2-mediated vasodilation is linked to disease progression and the degree of glycosuria, in aortas from non-obese diabetic mice (Roviezzo et al. 2005). In contrast, we reported that the initially preserved PAR2-mediated vasodilation became attenuated in aortas and mesenteric arteries under conditions of metabolic syndrome in older aged SHRSP.ZF (Kagota et al. 2014; Maruyama et al. 2016). The factors contributing to the age-related decline in PAR2 effects were unknown. In the present study, therefore, we investigated which factors in the phenotypic changes of SHRSP.ZF are relevant to the progressive decline in PAR2 vascular effects.

\section{Materials and methods}

\section{Experimental Animals.}

Male SHRSP.ZF established by the Disease Model Cooperative Research Association

(Hamamatsu, Japan) were purchased from Japan SLC, Inc. (Hamamatsu, Japan). Rats were provided a standard chow (CE-2; Clea Japan Inc., Tokyo, Japan) and water ad libitum during the experimental period. In total, thirty animals were used in the experiments. SHRSP.ZF at 10, 20 
and 30 wks ( $n=5$ for each group) were used in the first series of experiments to determine aortic ring vasodilation, and mRNA and protein expressions of PAR2 and sGC. A second set of SHRSP.ZF at 10, 20 and 30 wks ( $n=5$ for each group) were used in a follow-up series to assess the direct effects of a cGMP-analog on vascular tone and the cGMP accumulation elicited by 2-furoyl-LIGRLO-amide (2fLIGRLO), a synthetic PAR2 activating peptide (McGuire et al. 2004), in aortas. All protocols involving animals were approved by the animal ethics committee and performed in accordance with the Guidelines for the Care and Use of Laboratory Animals at Mukogawa Women's University.

\section{Determination of Metabolic Parameters}

Systolic blood pressure was measured by a tail-cuff method using a blood pressure monitor (Model MK-2000, Muromachi Kikai Co., Ltd., Tokyo, Japan), as previously described (Kubota et al. 2006). Blood pressure data were collected 1 week before the experimental date of the vasodilation studies. On the day of myograph experiments, after measuring body weight, body length and waist length, non-fasted blood was drawn from the abdominal aorta of each rat under anesthesia (sodium pentobarbital, $65 \mathrm{mg} / \mathrm{kg}$, i.p.). The serum was separated by centrifugation at 
$1,000 \mathrm{x} \mathrm{g}$ for $10 \mathrm{~min}$ at $4^{\circ} \mathrm{C}$. Serum levels of triglycerides, glucose and thiobarbituric acid reactive substances (TBARS) were determined using the commercial kits Triglyceride E-test Wako, Glucose CII-test Wako (Wako Pure Chemical Ind., Ltd., Osaka, Japan), and TBARS Assay Kit (Cayman Chemical Co., Ann Arbor, MI), respectively. Urine was collected from each bladder by needle puncture, and glucose was determined using UROPAPER III 'Eiken' (E-UR80, Eiken Chemical Co., LTD., Tochigi, Japan).

\section{Vascular Function Studies}

PAR2-mediated vasodilation of isolated aortas was determined using the organ bath methods as reported previously (Kagota et al. 2006). Briefly, thoracic aortas were removed from each animal under anesthesia, and immediately placed in Krebs-Henseleit solution $(118.4 \mathrm{mM} \mathrm{NaCl}$, $4.7 \mathrm{mM} \mathrm{KCl}, 2.5 \mathrm{mM} \mathrm{CaCl} \cdot 2 \mathrm{H}_{2} \mathrm{O}, 1.2 \mathrm{mM} \mathrm{KH}{ }_{2} \mathrm{PO}_{4}, 1.2 \mathrm{mM} \mathrm{MgSO} \cdot \cdot 7 \mathrm{H}_{2} \mathrm{O}, 25.0 \mathrm{mM}$ $\mathrm{NaHCO}_{3}, 11.1 \mathrm{mM}$ glucose). Each aorta was cut into $3 \mathrm{~mm}$ rings and mounted isometrically at an optimal resting tension of $1.0 \mathrm{~g}$ in a $10 \mathrm{~mL}$ organ bath filled with buffer solution $\left(37^{\circ} \mathrm{C}, \mathrm{pH}\right.$ 7.4). Isometric contractions in response to addition of cumulative concentrations of phenylephrine $(0.1 \mathrm{nM}-3.0 \mu \mathrm{M})$ were recorded for each aortic ring. After washout and 
equilibration at resting tension, $0.1 \mu \mathrm{M}$ phenylephrine (produces approximately $80 \%$ of the maximum contraction) was added to produce a stable level of tone and relaxation responses were determined by adding 2fLIGRLO (0.1 nM-3.0 $\mu \mathrm{M}$, Peptide Institute, Inc., Osaka, Japan), trypsin, an enzymatic PAR2 agonist (McGuire et al. 2002), (0.01-30 nM, IX-S porcine pancreas, molecular weight $23.8 \mathrm{kDa}, 13,000-20,000$ BAEE units/mg, T0303, Sigma Aldrich, Co., MO, USA), or sodium nitroprusside (SNP, $0.1 \mathrm{nM}-3.0 \mu \mathrm{M}$ ); cumulative concentrations of agonists are noted in parentheses. The relaxation responses were expressed as a percentage of the maximal relaxation by adding $100 \mu \mathrm{M}$ papaverine, a cyclic AMP phosphodiesterase inhibitor that mediates smooth muscle relaxation via a mechanism independent of NO and endothelium-dependent hyperpolarization factors (Kaneda et al. 1998; Sunagane et al. 1983). Representative tracings of the protocol for determining 2fLIGRLO-induced relaxation are provided in supplementary Fig. S1. In a separate series of experiments, relaxation was measured following the addition of 8-(4-chloro-phenylthio)-cGMP (8-pCPT-cGMP, $100 \mu \mathrm{M}$, Sigma Aldrich), a cell-permeable cGMP analog.

\section{Determination of Cyclic GMP (cGMP) Levels}


Aortic rings from SHRSP.ZF were mounted under isometric conditions as described above for vasodilation studies and exposed to phenylephrine $(0.1 \mu \mathrm{M})$ for $5 \mathrm{~min}$, and then treated with 2fLIGRLO $(1 \mu \mathrm{M})$ or vehicle (control) for $1 \mathrm{~min}$. cGMP levels in these aortas were measured using an enzyme-immunoassay (Amersham Biotrak System supplied by GE healthcare, Buckinghamshire, UK) as described previously (Kagota et al. 2006). The cGMP accumulation in control and treatment groups was calculated as fmoles cGMP per $\mu \mathrm{g}$ protein in each sample.

Treatment group data were expressed as the fold-increase relative to the control (vehicle). The protein concentration was determined using a BCA protein assay kit (Pierce Biotechnology Inc., Rockford, IL, USA).

\section{Quantitative Real-Time PCR Assay}

To examine PAR2 mRNA expression in aortas of SHRSP.ZF, quantitative real-time PCR assays were performed as previously described (Kagota et al. 2014). Aortic samples were isolated as described above, frozen in liquid nitrogen, and total RNA was extracted from tissues. RNA (80 ng) was purified using the RNeasy fibrous tissue kit, according to the manufacturer's instructions (Qiagen, Mississauga, Ontario, Canada). Real-time measurements of target gene 
expression were carried out using TaqMan RNA-to-CT 1-step kit and a LightCycler 1.5 (Roche

Diagnostics Japan K.K., Tokyo, Japan). Commercially available gene-specific probes were used (Roche Applied Science, Universal ProbeLibrary product ID: PAR2, 04685059001; ribosomal protein 18S, 04688937001), and gene-specific primers designed by Assay Design Center (Roche Applied Science) were purchased from Life Technologies Japan, Ltd. (Tokyo, Japan). The amount of target gene was normalized to the reference gene to obtain the relative threshold cycle $\left(\Delta \mathrm{C}_{\mathrm{T}}\right)$, and then related to the $\mathrm{C}_{\mathrm{T}}$ of the level at 10 wks to obtain the relative expression level $\left(2^{-\Delta \Delta C \mathrm{~T}}\right)$ of target gene.

\section{Western Blot Analysis}

Aortas isolated from SHRSP.ZF were homogenized using a glass homogenizer in buffer containing $50 \mathrm{mM}$ Tris- $\mathrm{HCl}(\mathrm{pH}$ 7.5), $150 \mathrm{mM} \mathrm{NaCl}, 10 \mathrm{mM}$ EDTA, 0.1\% Tween-20, 0.01\% (v/v) protease inhibitor cocktail (Sigma Chemical Co.) and phosphatase inhibitor cocktail (Nacalai Tesque Inc., Kyoto, Japan). The amount of target protein present in each sample (10 $\mu \mathrm{g}$ ) was determined by western blot analysis, as described previously (Kagota et al. 2009). Commercially available specific antibodies were used PAR2 (sc-13504, an anti-mouse 
monoclonal antibody that targets PAR2 amino acid sequence 37 to 50, Santa Cruz

Biotechnology, Inc., CA, USA), sGC (ab24824, Abcam, Inc., Cambridge, MA, USA), and

$\beta$-actin (A5316, Sigma Chemical Co.), and the appropriate horseradish peroxidase-coupled secondary antibody. Mouse NIH/3T3 whole cell lysates (SC-2210, Santa Cruz Biotechnology, Inc.) were used as a positive control for PAR2 and were loaded onto gels together with samples. Prestained protein ladder (161-0324, Bio-Rad Laboratories, Inc., Berkeley, CA, USA) was also loaded for use as size standards. Immunoreactive bands on membranes were recorded on an X-ray film and quantified by ImageJ (ver. 1.44). $\beta$-actin was used as an internal (loading) control. Data were expressed as the fold-increase to $10 \mathrm{wks}$. Representative immunoblots are from western blot experiments that were independently repeated three times.

\section{Statistical Analysis}

Data are expressed as means \pm standard error of the mean (SEM); $n=$ number of animals per group. Individual concentration-response curves for 2fLIGRLO, trypsin and SNP were analyzed by nonlinear regression curve fitting of drug concentration-relaxation response relationships to determine the negative $\log \mathrm{EC}_{50}$ and $\mathrm{E}_{\max }$ values using GraphPad Prism ${ }^{\circledR}$ (ver. 5.0, GraphPad 
software, La Jolla, CA, USA). Group comparisons at 10, 20 and 30 wks were made using one-way ANOVA followed by Bonferroni post-hoc test in GraphPad Prism ${ }^{\circledR}$. To examine the factors that had affected the PAR2-mediated relaxations, linear regression analysis and forward stepwise multiple regression analysis were performed using GraphPad Prism ${ }^{\circledR}$ and using Mulcel ${ }^{\circledR}$ (add-in software for Microsoft Excel, OMS publishing Inc., Saitama, Japan), respectively. Values of $P<0.05$ were considered significant.

\section{Results}

\section{Metabolic parameters of SHRSP.ZF}

Key phenotype characteristics of 10-30 weeks aged SHRSP.ZF (metabolism and hemodynamics) are summarized in Table 1. Previous studies show that SHRSP.ZF at 12 and 15 wks have heavier body weights, higher blood pressures, and metabolic abnormalities (higher serum levels of triglycerides and glucose) than those of normal control Wistar-Kyoto rats (Hiraoka-Yamamoto et al. 2004; Kunimasa et al. 2010). Similar to these findings, at 10 wks, SHRSP.ZF already displayed a metabolic syndrome phenotype. Body weight was gradually increased between 10 and $20 \mathrm{wks}$, and was retained at the same level until $30 \mathrm{wks}$. Waist length 
to body length ratio, an index of abdominal obesity, and systolic blood pressure were also retained at the same levels until 30 wks. Serum levels of triglycerides were greater at $20 \mathrm{wks}$ than at $10 \mathrm{wks}$, and this higher level was the same at $30 \mathrm{wks}$. In contrast, the serum level of glucose was lower at $30 \mathrm{wks}$ than that at $20 \mathrm{wks}$, and glucose in urine was not detected in SHRSP.ZF at any age $(<50 \mathrm{mg} / 100 \mathrm{~mL})$. The serum level of TBARS increased with ageing, and this level at 30 wks was almost two-fold the level at $10 \mathrm{wks}$.

\section{Changes in vasodilation via PAR2 activation in aortas from SHRSP.ZF}

Vasodilation in response to a synthetic PAR2-activating peptide, 2fLIGRLO, was sustained until $20 \mathrm{wks}$, but the vasodilation was decreased at $30 \mathrm{wks}$ compared with that at 10 and $20 \mathrm{wks}$ (Fig. 1A, Table 2). Similar to 2fLIGRLO, vasodilation induced by an enzyme-mediated PAR2 agonist, trypsin, was sustained until 20 wks and decreased at 30 wks (Fig. 1B, Table 2). In contrast, SNP-induced vasodilation was attenuated at 20 wks compared to that at $10 \mathrm{wks}$, and that was gradually less at 30 wks than 10 and 20 wks (Fig. 1C, Table 2). The relaxation response to 8-pCPT-cGMP, a stable cGMP analog, was unchanged at $20 \mathrm{wks}$ compared to that at $10 \mathrm{wks}$, but that was significantly decreased at $30 \mathrm{wks}$ compared to that at 10 and $20 \mathrm{wks}$ (Fig. 1D). At 
10 and 20 wks, 2fLIGRLO increased cGMP levels in aortas to approximately 13- and 9-fold respectively compared with that of the control (Fig. 1E). However, the level was approximately only 3 -fold higher at $30 \mathrm{wks}$, and the increment was significantly less than that at 10 and $20 \mathrm{wks}$ (Fig. 1E). Baseline cGMP levels in vehicle-treated controls were not different among the three groups (10 wks: $0.46 \pm 0.11,20$ wks: $0.59 \pm 0.32,30$ wks: $1.39 \pm 0.49 \mathrm{fmol} \mathrm{cGMP} / \mu \mathrm{g}$ protein, $n$ $=5$ ). $\mathrm{sGC}$ protein expression was decreased at 20 and $30 \mathrm{wks}$ compared to that at $10 \mathrm{wks}$ (Fig. $1 \mathrm{~F})$.

Contractile responses to phenylephrine were increased slightly at 20 and 30 wks compared to that at 10 wks (supplementary Fig. S2); however, as noted above, PAR2-mediated vasodilation at 20 wks was not affected by the increased contractility.

\section{Changes in protein and mRNA levels of PAR2 in aortas from SHRSP.ZF}

There was no significant difference in PAR2 protein expression in aortas from SHRSP.ZF between at 10 and 20 wks, but the level was decreased at 30 wks (Fig. 2A and 2B). Similar to the protein data, a decrease in PAR2 mRNA level was observed at 30 wks (Fig. 2C). The PAR2 protein expression was positively correlated with the mRNA expression (Fig. 2D). 


\section{Mechanisms of age-related decreases in PAR2 function in SHRSP.ZF}

To examine the factors that affected the PAR2-mediated vasodilation in SHRSP.ZF, the relationships between the $\mathrm{E}_{\max }$ values for $2 \mathrm{fLIGRLO}$ and trypsin, as indices of the vascular smooth muscle relaxation response, and individual metabolic parameters (i.e., body weight, systolic blood pressure, serum lipids and TBARS levels etc.) were examined using linear regression analyses. $\mathrm{E}_{\max }$ values for both $2 \mathrm{fLIGRLO}$ and trypsin positively correlated with increasing PAR2 mRNA expression (Fig. 3A and 3B). In addition, PAR2 protein expression was also positively associated with vasodilation induced by either of the PAR2 agonists (Fig. 3C and 3D). Furthermore, the $E_{\max }$ values of these PAR2 agonists were negatively correlated with higher systolic blood pressures in the individual rats (Fig. 4A and 4B). The $\mathrm{E}_{\max }$ values of PAR2 agonists were also negatively correlated with serum TBARS levels (Fig. 4C and 4D). In contrast, there were no correlations between the relaxations and body weight, waist length to body length ratio, as an index of abdominal obesity, serum levels of triglycerides or glucose (supplementary Fig. S3). 
For the four parameters - systolic blood pressure, serum TBARS levels, PAR2 mRNA and protein expressions - we determined which parameter(s) was strongly associated with the impairment of vasodilation using forward stepwise multiple regression analyses. A parameter of 2fLIGRLO-induced relaxation, $\mathrm{E}_{\max }$, was strongly related to TBARS levels and PAR2 protein expressions $(P<0.01$; Table 3$)$. Similar to 2 fLIGRLO, trypsin-induced relaxation was correlated with TBARS levels and PAR2 protein expressions $(P=0.011$; Table 3$)$. Furthermore, PAR2 protein expression was strongly associated with mRNA expressions $(P<0.01)$, and mRNA expression was strongly affected by TBARS levels $(P=0.039$; Table 4$)$.

\section{Discussion}

Our current study demonstrates that a decreasing in PAR2 expression on vascular endothelium occurs together with reduced responsiveness to NO in smooth muscle cells, leading to attenuation of vasodilation via PAR2 activation, in aortas from aged SHRSP.ZF with metabolic syndrome. Using aged rats with metabolic disorders, studies have reported that PAR2-mediated vasodilation of isolated arteries is preserved in cerebral arteries from high fat diet-induced hyperlipidemic Sprague-Dawley rats at 22-27 wks (Howitt et al. 2014), while 
being enhanced in cerebral arteries from SHR at 24-44 wks (Sobey et al. 1999) and mesenteric arteries from Goto-Kakizaki rats with type 2 diabetes at 32-40 wks (Matsumoto et al. 2009). In contrast, we reported that PAR2-mediated vasodilation was attenuated in aortas from aged SHRSP.ZF with metabolic syndrome (Maruyama et al. 2016). In the present study, the serum TBARS data suggest that oxidative stress might play an important role in decreasing levels of PAR2 protein and mRNA expression in aged metabolic syndrome rats. Further work is warranted to test the detailed mechanisms by which oxidative stress may act as a mediator to regulate PAR2 expression leading to development of impaired PAR2-mediated vasodilation at later stage of metabolic syndrome, which is a chronic condition that worsens with age.

Previous studies have reported differences in vasodilator responses between PAR2-activating peptides and enzyme activation of PAR2 under pathological conditions. For instance, PAR2-activating peptide-induced relaxation is increased, but trypsin is unchanged in cerebral arteries from SHR (Sobey et al. 1999). In another example, trypsin-induced relaxation was significantly reduced, but PAR2-activating peptide-induced relaxation was unchanged in pulmonary arteries from hypoxia-induced pulmonary hypertensive rats (Wanstall and Gambino 2004). These reports suggested that the decrease in enzyme-mediated effects might be explained 
by the presence of antitrypsin or a truncated amino-terminus form of PAR2 in the vessel wall (Sobey et al. 1999; Wanstall and Gambino 2004). In the present study, we compared the vasodilator response between two kinds of PAR2 agonist 2fLIGRLO, the synthetic-peptide (McGuire et al. 2004), and trypsin, the archetypal serine protease (McGuire et al. 2002). In contrast to the examples above, our current study indicates that impairment of vasodilation in response to trypsin occurred in aged SHRSP.ZF and was similar to the attenuation of responses by PAR2-activating peptide. These findings suggest that ageing or long-term exposure to metabolic disorders leads to impairments of PAR2 function in vascular beds in metabolic syndrome. Unlike the examples above, these data exclude the notion that modulation of the tethered-ligand activation of PAR2 contributes to the mechanism underlying the dysfunction.

In the present study, we found that the PAR2-mediated vasodilation was positively correlated with PAR2 protein and mRNA expressions in aortas of SHRSP.ZF. Previous studies have revealed that increased PAR2 mRNA and protein expressions in arteries are observed under conditions of the enhancement of PAR2-mediated vasodilation in coronary arteries of diabetic mice (Park et al. 2011), in mesenteric arteries of diabetic rats (Matsumoto et al. 2009), and in aortas of hypertensive rats (Aman et al. 2010). These findings and our data may indicate the 
possibility that the vasorelaxing response to PAR2 is regulated in parallel with its expression in vascular beds under disease conditions.

Indices of oxidative stress increase in the plasma of overweight humans (Vincent et al. 2010) and hypertension patients (Russo et al. 1998), and in the urine of metabolic syndrome patients (Fujita et al. 2006). A present study shows that serum TBARS levels, an index of oxidative stress, increases in SHRSP.ZF with ageing. In their review of literature on the topic of oxidative stress markers, Ho et al. (2013) reported that serum TBARS levels did not necessarily correlate with increased oxidative stress at the tissue levels. However, in our case, it is known that the production of superoxide increases at the cellular level in SHRSP.ZF arteries (Kagota et al. 2010) and accompanies increased serum TBARS levels (Kagota et al. 2014). In addition, intravascular superoxide generation measured by semi-quantitative methods using DHE is increased in obese Zucker rats (Phillips et al. 2005) and SHR (He et al. 2011), the originating genetic strains used for deriving the SHRSP.ZF. Additionally, NO-mediated vasodilation is improved by treating tissues/animals with TEMPOL, a membrane permeable superoxide scavenger/superoxide dismutase mimetic, in obese Zucker rats (Romanko and Stepp 2005) and the SHRSP.ZF (Kagota et al. 2013); TEMPOL treatments also reduced serum TBARS levels in 
SHRSP.ZF. The present study indicates that PAR2-mediated vasodilation was negatively correlated with serum TBARS level in SHRSP.ZF. The correlations between vasodilation and each of the other metabolic parameters i.e. body weight, waist length to body length ratio, serum levels of triglycerides and glucose, were not significant. Moreover, the amount of PAR2 protein was strongly associated with its mRNA level, and mRNA levels were strongly associated with oxidative stress, according to stepwise multiple regression analysis. These findings suggest that oxidative stress may play an important role in regulating PAR2 expressions on the endothelium in aged SHRSP.ZF, leading to deterioration of the vasodilation. Increasing levels of oxidative stress with ageing is proposed to cause DNA damage and mitochondrial dysfunction (Beckman and Ames 1998; Bonomini et al. 2015; Cortopassi et al. 1992; Shigenaga et al. 1994). Generally, oxidative stress is proposed to precede the development of cardiovascular disease (Gioscia-Ryan et al. 2014; Kagota et al. 2010; Kagota et al. 2013; Kagota et al. 2009; Limberg et al. 2013). Further studies are needed to elucidate the mechanism by which oxidative stress may act to specifically mediate regulation of PAR2.

Currently, there remains more work to be done to uncover the physiological and pathological consequences of the impaired PAR2-mediated vasodilation at later stages of 
metabolic syndrome. Systolic blood pressures of $P A R 2$ knockout mice are modestly higher than wild-type PAR2 mice (McGuire et al. 2008), which may imply that loss of PAR2 expression may exacerbate blood pressures with age in the SHRSP.ZF. Indeed we found that the blood pressure of SHRSP.ZF at 30 wks was slightly higher (about $10 \mathrm{mmHg}$ ) than that at 20 wks. These findings raise the possibility that a decline in PAR2 function contributes to higher blood pressure, which may result in damage to organs such as the kidneys, cerebral vessels, and the heart.

In conclusion, our data shows that not only a reduced responsiveness towards NO in smooth muscle cells, but also a decreased PAR2 expression on vascular endothelium, leads to attenuation of PAR2-mediated vasodilation at a late stage of metabolic syndrome. Oxidative stress is proposed as a key mediator in the pathway to development of the vascular dysfunction in the SHRSP.ZF. Impairment of PAR2-mediated vasodilation may lead to reductions in circulation and promote the development of cardiovascular disease in metabolic syndrome.

\section{Acknowledgements}


The authors express sincere gratitude to Ms. Saki Iwata, Ms. Akiko Ogura and Ms. Natsumi Maruyama for technical assistance. This study was partly supported by MEXT KAKENHI (grant number 23590315).

\section{References}

Adams, M.N., Ramachandran, R., Yau, M.K., Suen, J.Y., Fairlie, D.P., Hollenberg, M.D., et al.

2011. Structure, function and pathophysiology of protease activated receptors. Pharmacol. Ther.

130(3): 248-282. doi: 10.1016/j.pharmthera.2011.01.003.

Aman, M., Hirano, M., Kanaide, H., and Hirano, K. 2010. Upregulation of Proteinase-Activated

Receptor-2 and Increased Response to Trypsin in Endothelial Cells after Exposure to Oxidative

Stress in Rat Aortas. J. Vasc. Res. 47(6): 494-506. doi: 10.1159/000313877.

Beckman, K.B., and Ames, B.N. 1998. The free radical theory of aging matures. Physiol. Rev.

78(2): $547-581$.

Bonomini, F., Rodella, L.F., and Rezzani, R. 2015. Metabolic syndrome, aging and involvement

of oxidative stress. Aging Dis. 6(2): 109-120. doi: 10.14336/AD.2014.0305. 
Bucci, M., Roviezzo, F., and Cirino, G. 2005. Protease-activated receptor-2 (PAR2) in cardiovascular system. Vascul. Pharmacol. 43(4): 247-253. doi: 10.1016/j.vph.2005.07.009.

Cortopassi, G.A., Shibata, D., Soong, N.W., and Arnheim, N. 1992. A pattern of accumulation of a somatic deletion of mitochondrial DNA in aging human tissues. Proc. Natl. Acad. Sci.

U.S.A. 89(16): 7370-7374.

Fujita, K., Nishizawa, H., Funahashi, T., Shimomura, I., and Shimabukuro, M. 2006. Systemic oxidative stress is associated with visceral fat accumulation and the metabolic syndrome. Circ. J.

70(11): 1437-1442. doi: 10.1253/circj.70.1437.

Gioscia-Ryan, R.A., LaRocca, T.J., Sindler, A.L., Zigler, M.C., Murphy, M.P., and Seals, D.R. 2014. Mitochondria-targeted antioxidant (MitoQ) ameliorates age-related arterial endothelial dysfunction in mice. J. Physiol. 592(Pt 12): 2549-2561. doi: 10.1113/jphysiol.2013.268680.

Hanson, R.L., Imperatore, G., Bennett, P.H., and Knowler, W.C. 2002. Components of the "metabolic syndrome" and incidence of type 2 diabetes. Diabetes, 51(10): 3120-3127. doi: 10.2337/diabetes.51.10.3120. 
He, X., Zhang, H.L., Zhao, M., Yang, J.L., Cheng, G., Sun, L., et al. 2011. Amlodipine ameliorates endothelial dysfunction in mesenteric arteries from spontaneously hypertensive rats.

Clin. Exp. Pharmacol. Physiol. 38(4): 255-261. doi: 10.1111/j.1440-1681.2011.05495.x.

Hiraoka-Yamamoto, J., Nara, Y., Yasui, N., Onobayashi, Y., Tsuchikura, S., and Ikeda, K. 2004.

Establishment of a new animal model of metabolic syndrome: SHRSP fatty (fa/fa) rats. Clin.

Exp. Pharmacol. Physiol. 31(1-2): 107-109. doi: 10.1111/j.1440-1681.2004.03962.x.

Ho, E., Karimi Galougahi, K., Liu, C.C., Bhindi, R., and Figtree, G.A. 2013. Biological markers of oxidative stress: Applications to cardiovascular research and practice. Redox. Biol. 1: 483-491. doi: 10.1016/j.redox.2013.07.006.

Howitt, L., Morris, M.J., Sandow, S.L., and Murphy, T.V. 2014. Effect of diet-induced obesity on $\mathrm{BK}(\mathrm{Ca})$ function in contraction and dilation of rat isolated middle cerebral artery. Vascul.

Pharmacol. 61(1): 10-15. doi: 10.1016/j.vph.2014.02.002.

Kagota, S., Chia, E., and McGuire, J.J. 2011. Preserved arterial vasodilatation via endothelial protease-activated receptor-2 in obese type 2 diabetic mice. Br. J. Pharmacol. 164(2): 358-371. doi: 10.1111/j.1476-5381.2011.01356.x. 
Kagota, S., Fukushima, K., Umetani, K., Tada, Y., Nejime, N., Nakamura, K., et al. 2010.

Coronary vascular dysfunction promoted by oxidative-nitrative stress in SHRSP.Z-Lepr(fa)

/IzmDmcr rats with metabolic syndrome. Clin. Exp. Pharmacol. Physiol. 37(11): 1035-1043.

doi: $10.1111 / \mathrm{j} .1440-1681.2010 .05432 . x$.

Kagota, S., Maruyama, K., and McGuire, J.J. 2016. Characterization and Functions of

Protease-Activated Receptor 2 in Obesity, Diabetes, and Metabolic Syndrome: A Systematic

Review. Biomed. Res. Int. 2016: 3130496. doi: 10.1155/2016/3130496.

Kagota, S., Maruyama, K., Tada, Y., Fukushima, K., Umetani, K., Wakuda, H., et al. 2013.

Chronic oxidative-nitrosative stress impairs coronary vasodilation in metabolic syndrome model

rats. Microvasc. Res. 88: 70-78. doi: 10.1016/j.mvr.2013.04.001.

Kagota, S., Maruyama, K., Wakuda, H., McGuire, J.J., Yoshikawa, N., Nakamura, K., et al.

2014. Disturbance of vasodilation via protease-activated receptor 2 in

SHRSP.Z-Leprfa/IzmDmcr rats with metabolic syndrome. Vascul. Pharmacol. 63(1): 46-54. doi:

10.1016/j.vph.2014.06.005.

Kagota, S., Tada, Y., Nejime, N., Nakamura, K., Kunitomo, M., and Shinozuka, K. 2009.

Chronic production of peroxynitrite in the vascular wall impairs vasorelaxation function in 
SHR/NDmcr-cp rats, an animal model of metabolic syndrome. J. Pharmacol. Sci. 109(4):

556-564. doi: 10.1254/jphs.08273FP.

Kagota, S., Yamaguchi, Y., Tanaka, N., Kubota, Y., Kobayashi, K., Nejime, N., et al. 2006.

Disturbances in nitric oxide/cyclic guanosine monophosphate system in SHR/NDmcr-cp rats, a

model of metabolic syndrome. Life Sci. 78(11): 1187-1196. doi: 10.1016/j.lfs.2005.06.029.

Kaneda, T., Shimizu, K., Nakajyo, S., and Urakawa, N. 1998. The difference in the inhibitory

mechanisms of papaverine on vascular and intestinal smooth muscles. Eur. J. Pharmacol.

355(2-3): 149-157. doi: 10.1016/S0014-2999(98)00479-8.

Kubota, Y., Umegaki, K., Kagota, S., Tanaka, N., Nakamura, K., Kunitomo, M., et al. 2006.

Evaluation of blood pressure measured by tail-cuff methods (without heating) in spontaneously

hypertensive rats. Biol. Pharm. Bull. 29(8): 1756-1758. doi: 10.1248/bpb.29.1756.

Kunimasa, K., Yoshitomi, H., Miura, C., Mori, H., Tsuchikura, S., Ikeda, K., et al. 2010. High susceptibility of obese hypertensive SHRSP.Z-Lepr(fa)/IzmDmcr rats to lipid deposition in the mesenteric artery. Clin. Exp. Pharmacol. Physiol. 37(11): 1102-1104. doi: 10.1111/j.1440-1681.2010.05440.x. 
Lakka, H.M., Laaksonen, D.E., Lakka, T.A., Niskanen, L.K., Kumpusalo, E., Tuomilehto, J., et al. 2002. The metabolic syndrome and total and cardiovascular disease mortality in middle-aged men. JAMA. 288(21): 2709-2716.

Limberg, J.K., Harrell, J.W., Johansson, R.E., Eldridge, M.W., Proctor, L.T., Sebranek, J.J., et al. 2013. Microvascular function in younger adults with obesity and metabolic syndrome: role of oxidative stress. Am. J. Physiol. Heart Circ. Physiol. 305(8): H1230-1237. doi: 10.1152/ajpheart.00291.2013.

Maruyama, K., Kagota, S., McGuire, J.J., Wakuda, H., Yoshikawa, N., Nakamura, K., et al. 2016. Enhanced Nitric Oxide Synthase Activation via Protease-Activated Receptor 2 Is Involved in the Preserved Vasodilation in Aortas from Metabolic Syndrome Rats. J. Vasc. Res. 52(4): 232-243. doi: 10.1159/000442415.

Matsumoto, T., Ishida, K., Taguchi, K., Kobayashi, T., and Kamata, K. 2009. Mechanisms underlying enhanced vasorelaxant response to protease-activated receptor 2-activating peptide in type 2 diabetic Goto-Kakizaki rat mesenteric artery. Peptides, 30(9): 1729-1734. doi: 10.1016/j.peptides.2009.06.014. 
McGuire, J.J., Hollenberg, M. D., Andrade-Gordon, P., and Triggle, C. R. 2002. Multiple mechanisms of vascular smooth muscle relaxation by the activation of Protease-Activated Receptor 2 in mouse mesenteric arterioles. Br. J. Pharmacol. 135: 155-169. doi: 10.1038/sj.bjp.0704469.

McGuire, J.J., Saifeddine, M., Triggle, C.R., Sun, K., and Hollenberg, M.D. 2004. 2-furoyl-LIGRLO-amide: a potent and selective proteinase-activated receptor 2 agonist. J. Pharmacol. Exp. Ther. 309(3): 1124-1131. doi: 10.1124/jpet.103.064584.

McGuire, J.J., Van Vliet, B.N., and Halfyard, S.J. 2008. Blood pressures, heart rate and locomotor activity during salt loading and angiotensin II infusion in protease-activated receptor 2 (PAR2) knockout mice. BMC Physiol. 8(1): 20. doi: 10.1186/1472-6793-8-20.

Park, Y., Yang, J., Zhang, H., Chen, X., and Zhang, C. 2011. Effect of PAR2 in regulating TNF- $\alpha$ and NAD(P)H oxidase in coronary arterioles in type 2 diabetic mice. Basic Res. Cardiol. 106(1): 111-123. doi: 10.1007/s00395-010-0129-9.

Phillips, S.A., Sylvester, F.A., and Frisbee, J.C. 2005. Oxidant stress and constrictor reactivity impair cerebral artery dilation in obese Zucker rats. Am. J. Physiol. Regul. Integr. Comp. Physiol. 288(2): R522-530. doi: 10.1152/ajpregu.00655.2004. 
Romanko, O.P., and Stepp, D.W. 2005. Reduced constrictor reactivity balances impaired vasodilation in the mesenteric circulation of the obese Zucker rat. Am. J. Physiol. Heart Circ.

Physiol. 289(5): H2097-2102. doi: 10.1152/ajpheart.00213.2005.

Roviezzo, F., Bucci, M., Brancaleone, V., Lorenzo, A.D., Geppetti, P., Farneti, S., et al. 2005.

Proteinase-Activated Receptor-2 Mediates Arterial Vasodilation in Diabetes. Arterioscler.

Thromb. Vasc. Biol. 25: 2349-2354. doi: 10.1161/01.ATV.0000184770.01494.2e.

Russo, C., Olivieri, O., Girelli, D., Faccini, G., Zenari, M.L., Lombardi, S., et al. 1998. Anti-oxidant status and lipid peroxidation in patients with essential hypertension. J. Hypertens.

16(9): 1267-1271.

Samad, F., and Ruf, W. 2013. Inflammation, obesity, and thrombosis. Blood, 122(20):

3415-3422. doi: 10.1182/blood-2013-05-427708.

Shigenaga, M.K., Hagen, T.M., and Ames, B.N. 1994. Oxidative damage and mitochondrial decay in aging. Proc. Natl. Acad. Sci. U.S.A. 91(23): 10771-10778.

Sobey, C.G., Moffatt, J.D., and Cocks, T.M. 1999. Evidence for Selective Effects of Chronic Hypertension on Cerebral Artery Vasodilatation to Protease-Activated Receptor-2 Activation.

Stroke, 30: 1933-1940. doi: 10.1161/01.STR.30.9.1933. 
Steinhoff, M., Buddenkotte, J., Shpacovitch, V., Rattenholl, A., Moormann, C., Vergnolle, N., et al. 2005. Proteinase-activated receptors: transducers of proteinase-mediated signaling in inflammation and immune response. Endocr. Rev. 26(1): 1-43. doi: 10.1210/er.2003-0025.

Sunagane, N., Sakata, T., Uruno, T., and Kubota, K. 1983. Mechanism of relaxant action of papaverine. III. Comparison of sodium ion dependencies on the relaxant effects of papverine, aspaminol and benactyzine in guinea-pig taenia coli. J. Pharmacobiodyn. 6: 466-474.

Vincent, H.K., Bourguignon, C.M., and Taylor, A.G. 2010. Relationship of the dietary phytochemical index to weight gain, oxidative stress and inflammation in overweight young adults. J. Hum. Nutr. Diet. 23(1): 20-29. doi: 10.1111/j.1365-277X.2009.00987.x.

Wanstall, J.C., and Gambino, A. 2004. Proteinase-activated receptor (PAR)-mediated vasorelaxation in pulmonary arteries from normotensive and hypoxic pulmonary hypertensive rats. Pulm. Pharmacol. Ther. 17(2): 97-103. doi: 10.1016/j.pupt.2003.11.002.

Yau, M.K., Liu, L., and Fairlie, D.P. 2013. Toward drugs for protease-activated receptor 2 (PAR2). J. Med. Chem. 56(19): 7477-7497. doi: 10.1021/jm400638v. 
Table 1. Metabolic parameters in SHRSP.Z-Lepr ${ }^{f a} /$ IzmDmcr rats at 10, 20 and 30 weeks of age (wks)

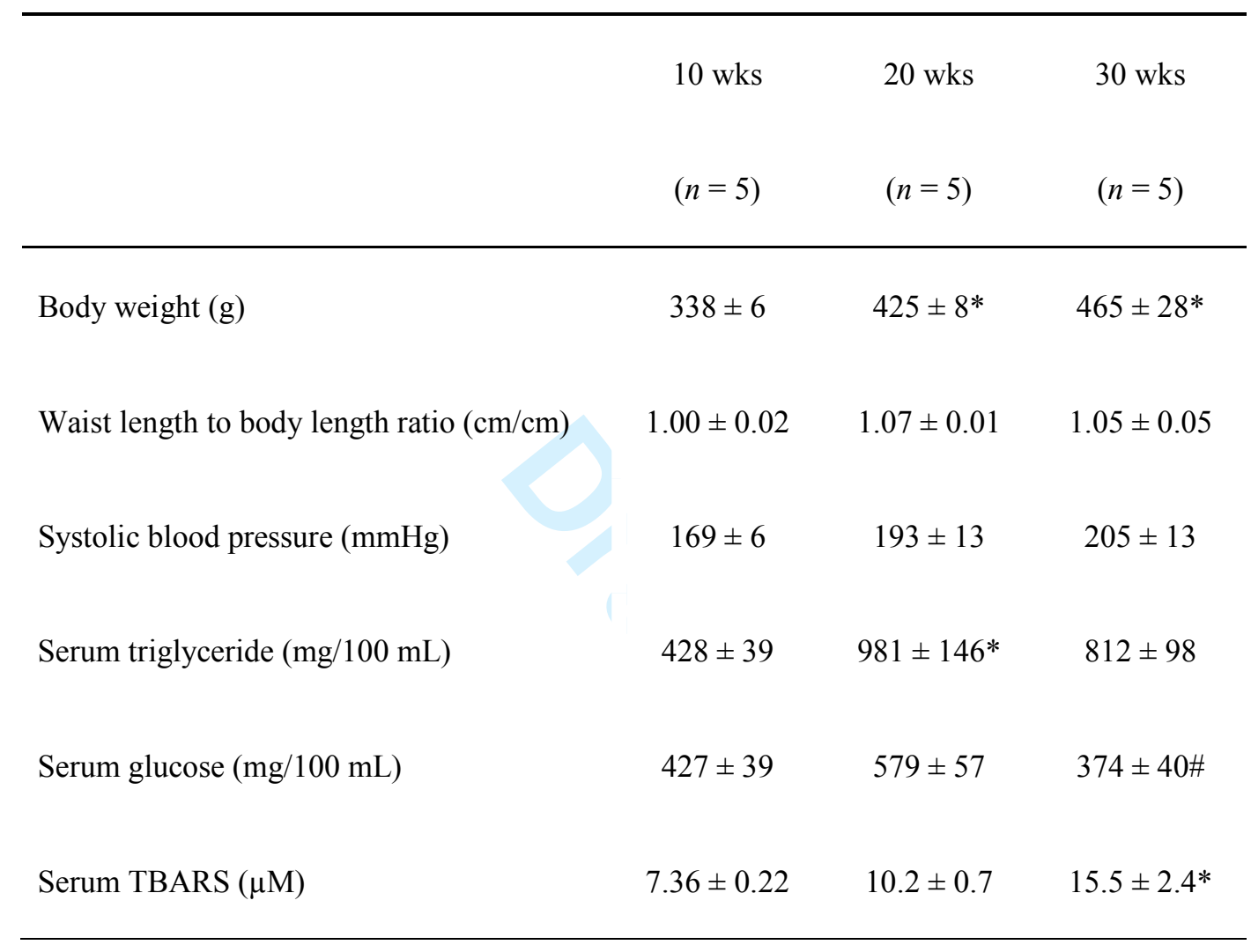

Note: Results are expressed as mean \pm SEM. ${ }^{*} P<0.05$, compared to that at $10 \mathrm{wks} ; \# P<0.05$, compared to that at $20 \mathrm{wks}$. 
Table 2. Parameters for concentration-relaxation response curves to 2 -furoyl-LIGRLO-amide (2fLIGRLO), trypsin, and sodium nitroprusside (SNP) in aortas from SHRSP.Z-Lepr ${ }^{f a} /$ IzmDmcr rats at 10, 20 and 30 weeks of age (wks)

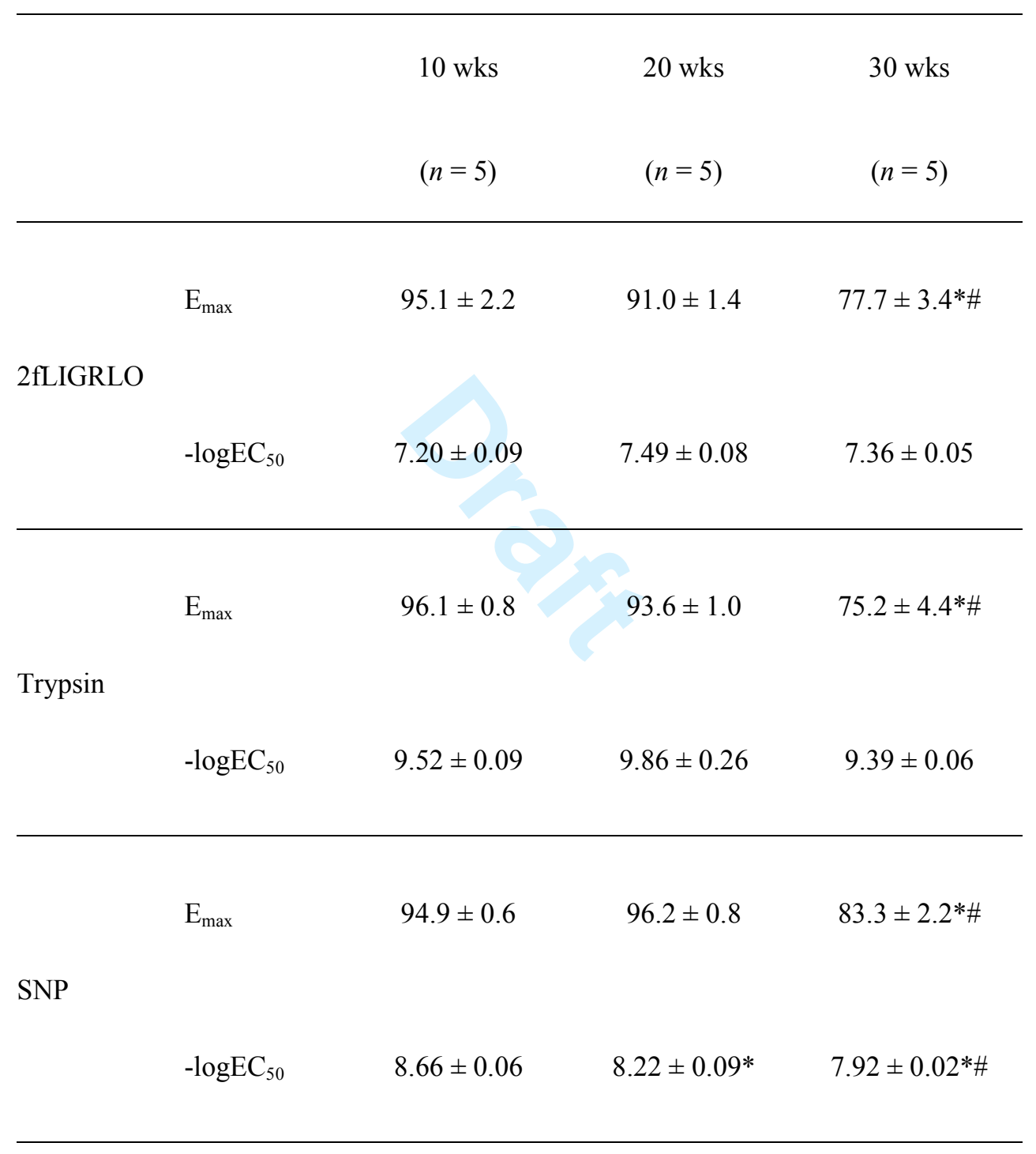

Note: Results are expressed as mean \pm SEM. ${ }^{*} P<0.05$, compared to that at $10 \mathrm{wks} ; \# P<0.05$, compared to that at $20 \mathrm{wks}$. 
Table 3. Stepwise multiple regression analysis for vasodilation in response to

2-furoyl-LIGRLO-amide (2fLIGRLO) and trypsin

\begin{tabular}{|c|c|c|c|c|}
\hline \multirow[t]{2}{*}{ Factor } & \multicolumn{2}{|c|}{ Relaxation to $2 \mathrm{fLIGRLO}\left(\mathrm{E}_{\max }\right)$} & \multicolumn{2}{|c|}{ Relaxation to trypsin $\left(\mathrm{E}_{\max }\right)$} \\
\hline & $\beta$ & $R^{2}$ & $\beta$ & $R^{2}$ \\
\hline \multirow[t]{2}{*}{ TBARS level } & -0.573 & & -0.444 & \\
\hline & & 0.711 & & 0.528 \\
\hline PAR2 protein expression & 0.426 & & 0.422 & \\
\hline
\end{tabular}

Note: Factors significantly associated with PAR2-mediated relaxations were selected for forward stepwise multiple regression analysis. $\beta$ is a standardized coefficient and the $R^{2}$ value is a coefficient of determination. $P<0.05, n=15$. 
Table 4. Stepwise multiple regression analysis for protease-activated receptor-2 (PAR2) expression

\begin{tabular}{lcccc}
\hline Factor & PAR2 protein expression & PAR2 mRNA expression \\
& $\beta$ & $R^{2}$ & $\beta$ & $R^{2}$ \\
\hline PAR2 mRNA expression & 0.646 & 0.418 & - & - \\
TBARS level & - & & & 0.289 \\
\hline
\end{tabular}

Note: Factors associated with PAR2 expressions were selected for forward stepwise multiple regression analysis. $\beta$ is a standardized coefficient and the $R^{2}$ value is a coefficient of determination. $P<0.05, n=15$. 


\section{Figure captions}

Fig. 1. Changes in vasodilation in response to 2-furoyl-LIGRLO-amide (2fLIGRLO; A), trypsin (B), sodium nitroprusside (SNP; C) and 8-(4-chloro-phenylthio)-cGMP (8-pCPT-cGMP; D), cGMP accumulation by treatment with 2 fLIGRLO (E) and protein expressions of soluble guanylyl cyclase (sGC, F) in aortas from SHRSP.Z-Lepr ${ }^{f a} /$ IzmDmcr rats (SHRSP.ZF) at 10, 20 and 30 weeks of age (wks). Results are expressed as mean \pm SEM. $* P<0.05$, compared to that at 10 wks; $\# P<0.05$, compared to that at 20 wks.

Fig. 2. Protein (A and B) and mRNA (C) expressions of protease-activated receptor 2 (PAR2) in aortas from SHRSP.Z-Lepr ${ }^{f a} / \mathrm{IzmDmcr}$ rats at 10, 20 and 30 weeks of age (wks), and correlation (D) between PAR2 protein and mRNA expression. Panel A shows representative blot images indicating immunoreactive bands corresponding to PAR2 in lanes containing positive control (Mouse NIH/3T3 whole cell lysates) and aortic protein samples; M indicates the lane containing prestained molecular marker. Panel B summarizes the densitometry data of three independent experiments. Results are expressed as the mean \pm SEM. ${ }^{*} P<0.05$, compared to that at $10 \mathrm{wks}$; $\# P<0.05$, compared to that at $20 \mathrm{wks}$. 
Fig. 3. Correlations between the maximum response $\left(\mathrm{E}_{\max }\right)$ of PAR2 agonists (2-furoyl-LIGRLO-amide (2fLIGRLO); trypsin) with PAR2 mRNA, and protein expression in aortas from SHRSP.Z-Lepr ${ }^{f a} /$ IzmDmcr rats (SHRSP.ZF).

Fig. 4. Correlations between the maximum response $\left(E_{\max }\right)$ of PAR2 agonists (2-furoyl-LIGRLO-amide (2fLIGRLO); trypsin) with systolic blood pressure, and serum thiobarbituric acid reactive substances (TBARS), an index of oxidative stress, in SHRSP.Z-Lepr ${ }^{f a} /$ IzmDmcr rats (SHRSP.ZF). 
Fig. 1 Maruyama et al.

A

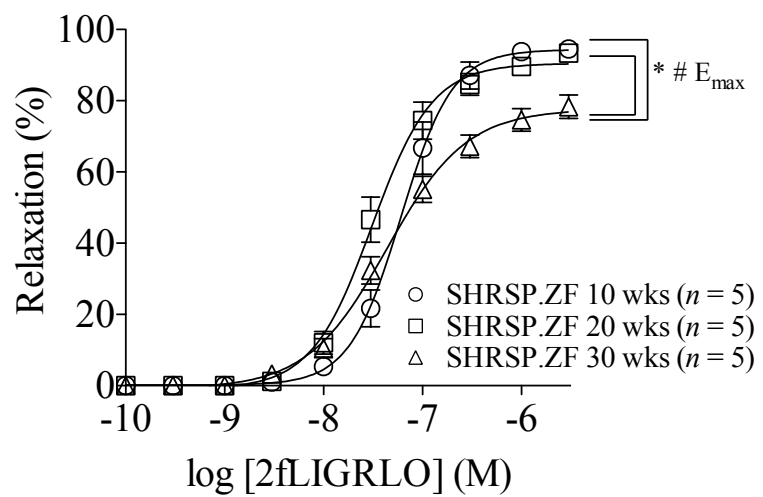

C

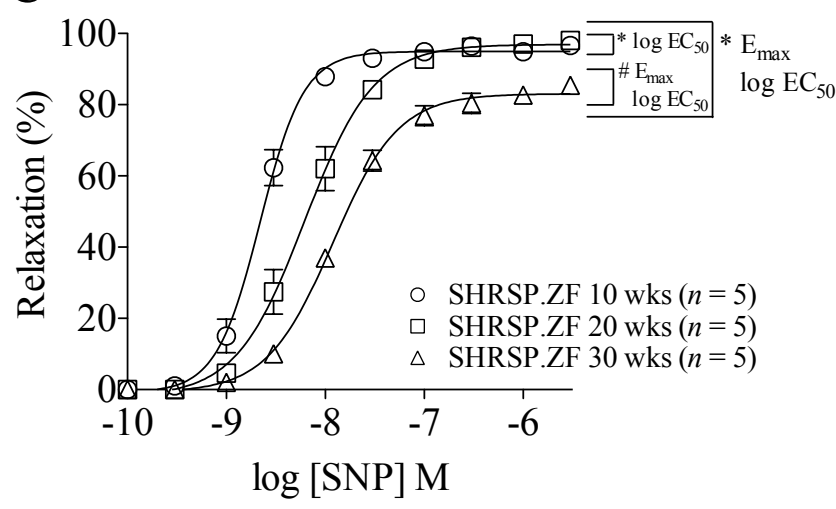

E

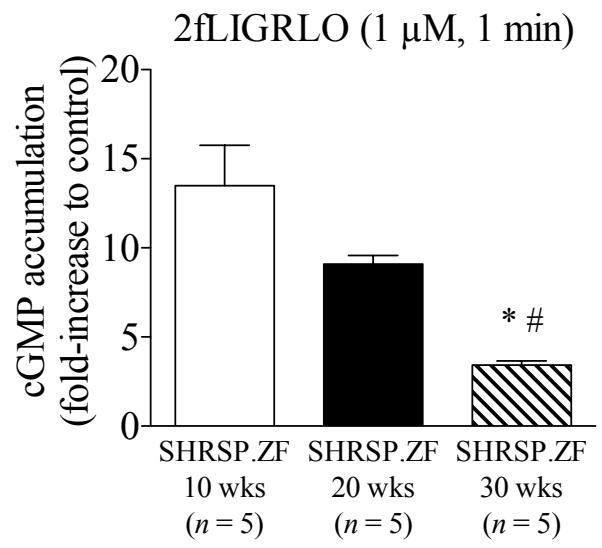

B

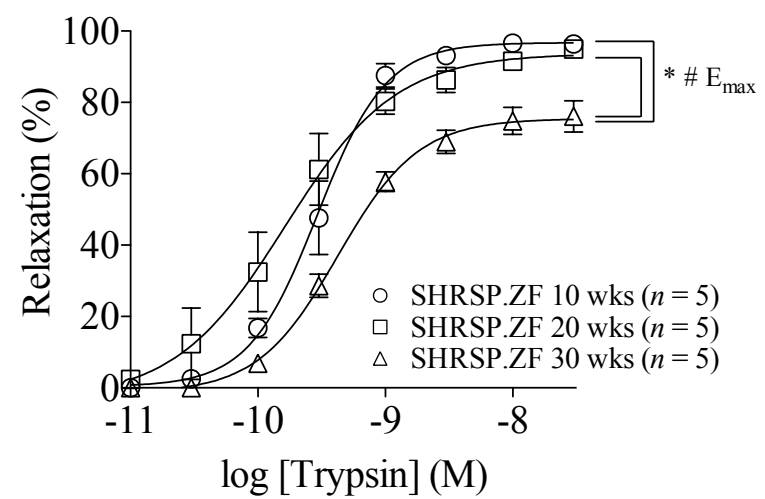

D 8-pCPT-cGMP $(100 \mu \mathrm{M})$
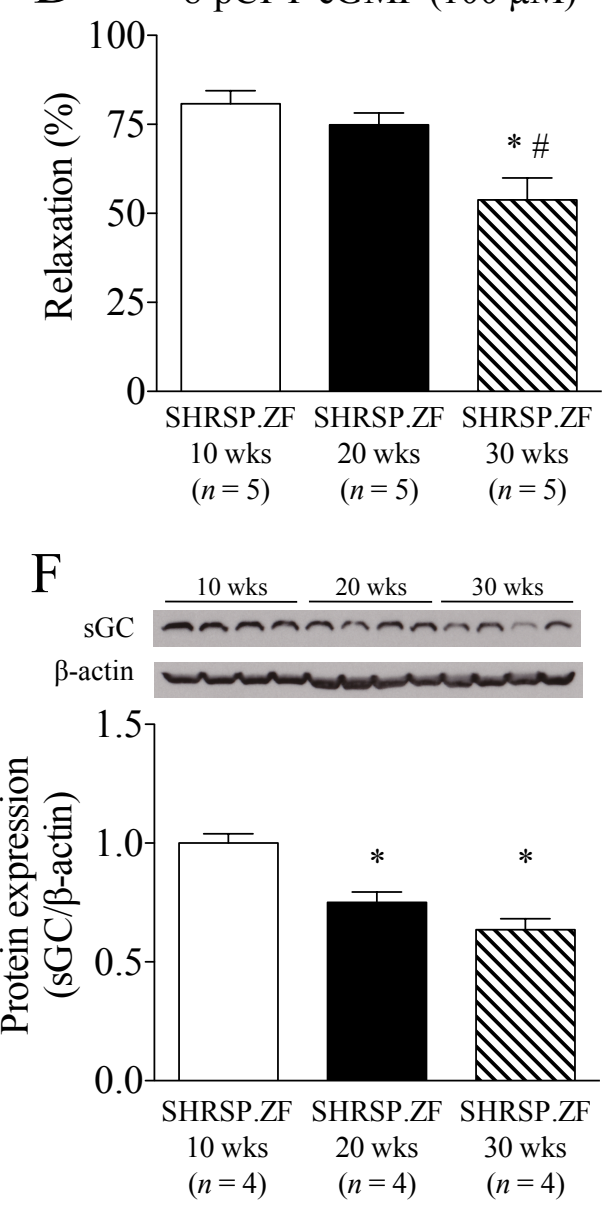
Fig. 2 Maruyama et al.

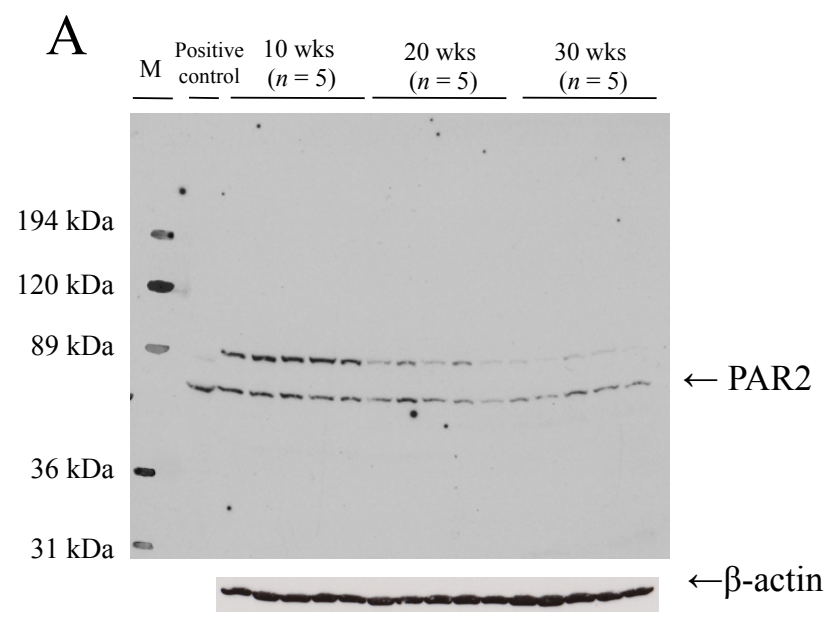

B

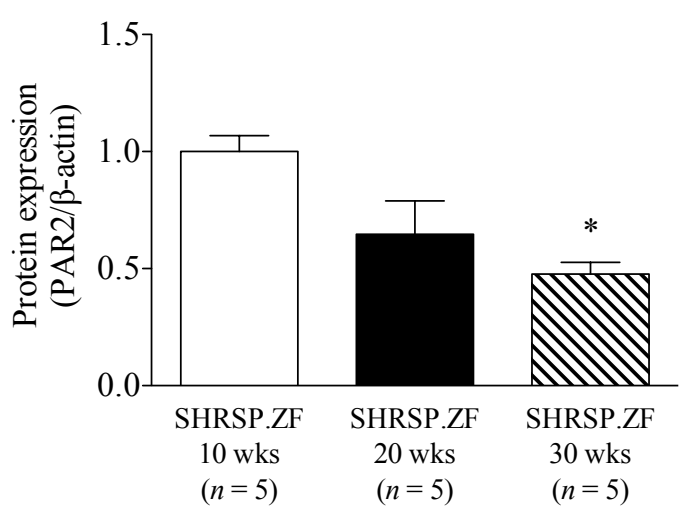

C

D
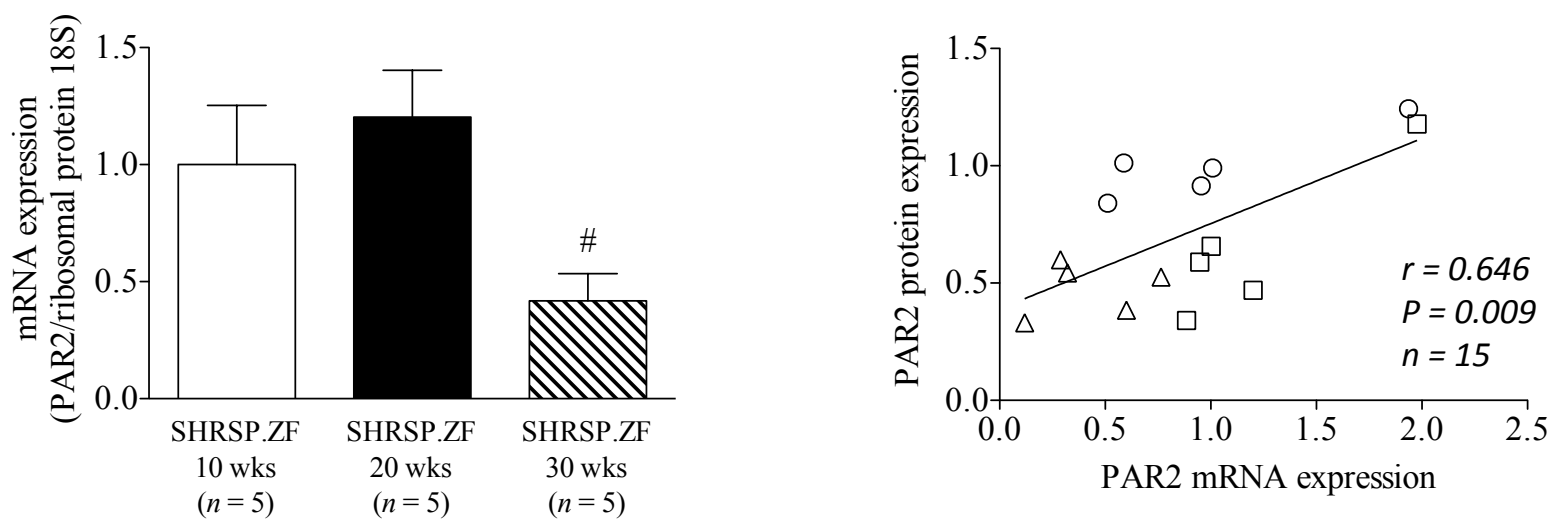

○ SHRSP.ZF 10 wks $(n=5)$

$\square$ SHRSP.ZF $20 \mathrm{wks}(n=5)$

$\triangle$ SHRSP.ZF $30 \mathrm{wks}(n=5)$ 
Fig. 3 Maruyama et al.

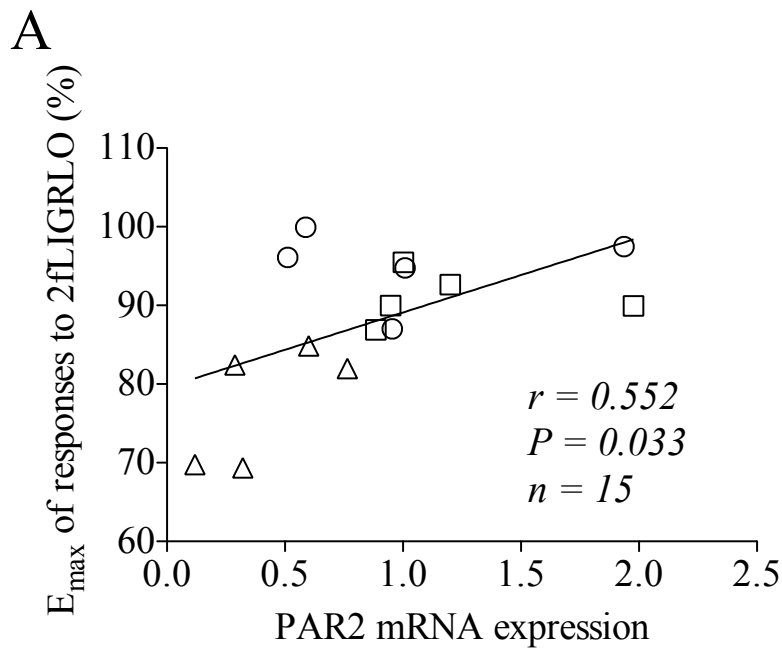

B
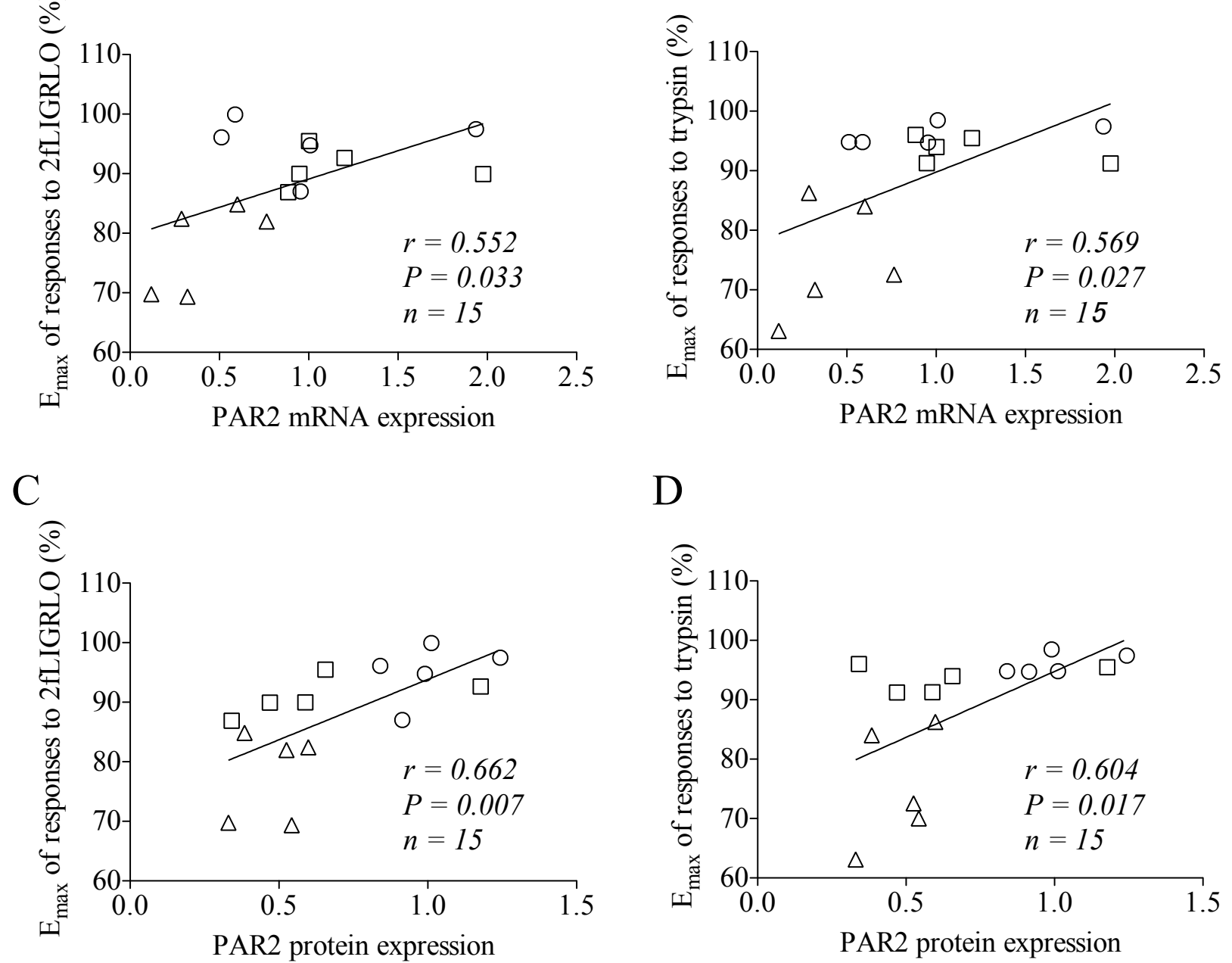

D

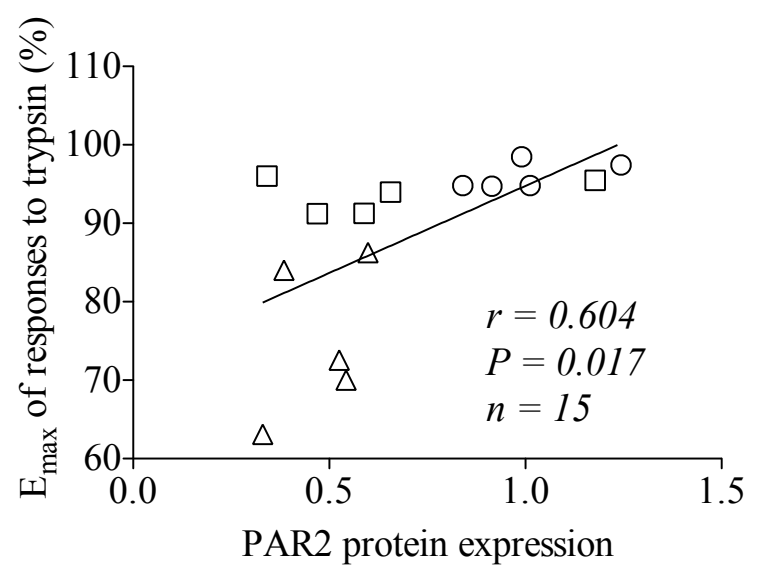

○ SHRSP.ZF 10 wks $(n=5)$

$\square$ SHRSP.ZF 20 wks $(n=5)$

$\triangle$ SHRSP.ZF 30 wks $(n=5)$ 
Fig. 4 Maruyama et al.

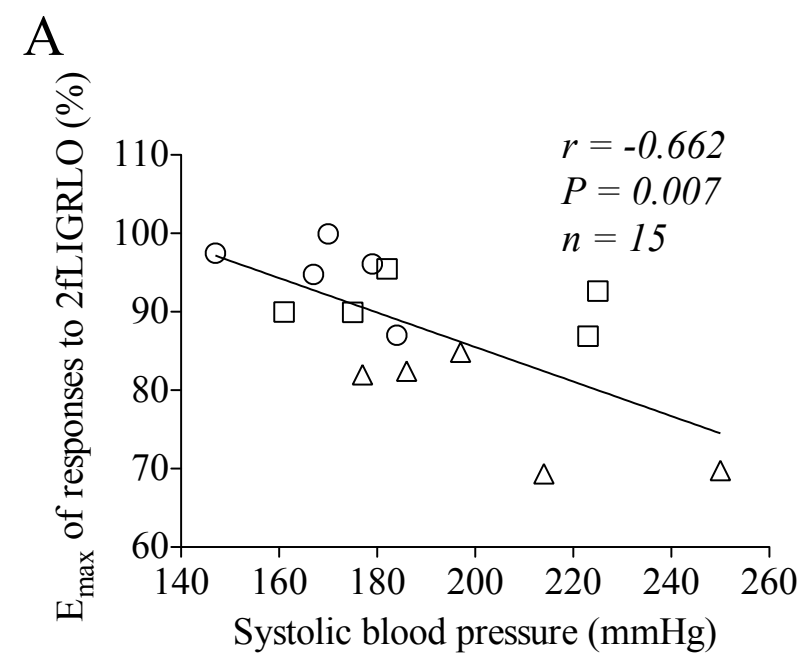

B

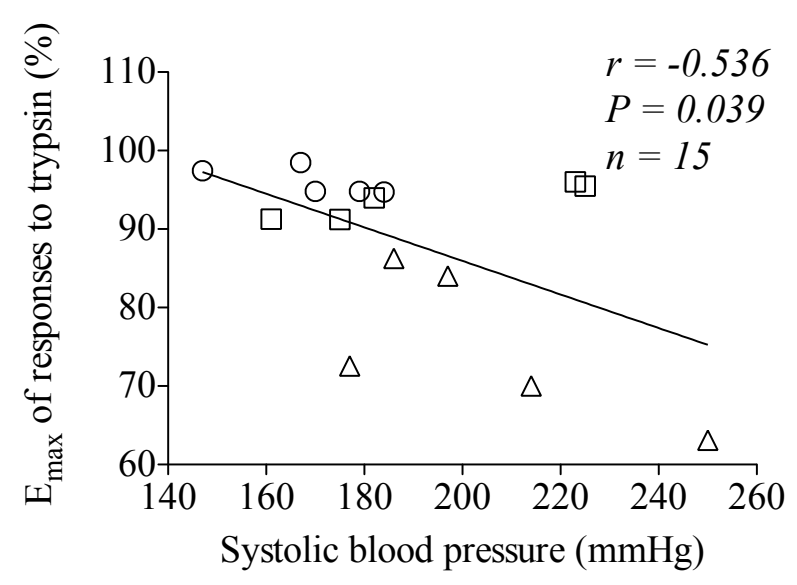

$\mathrm{C}$

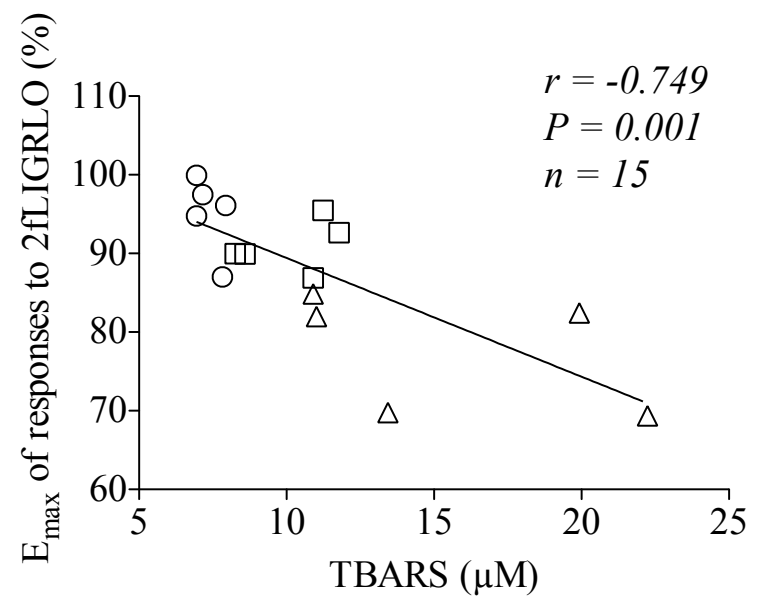

D

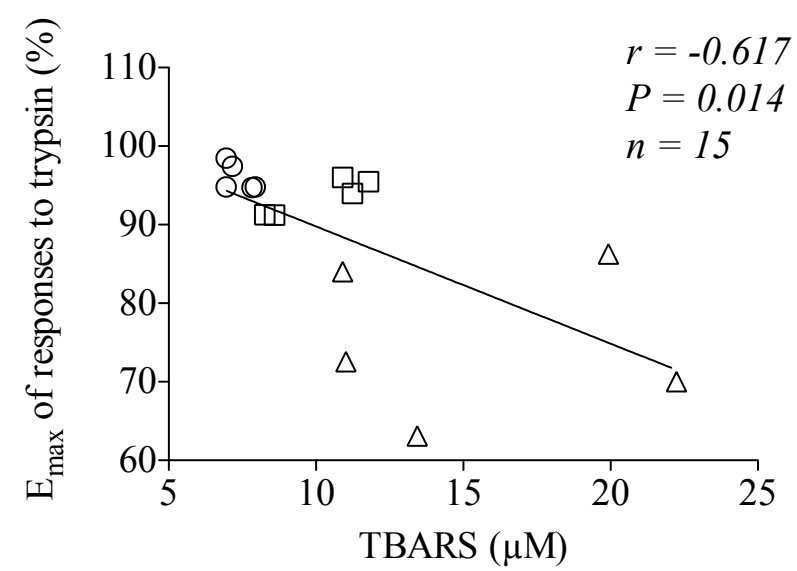

○ SHRSP.ZF 10 wks $(n=5)$

$\square$ SHRSP.ZF $20 \mathrm{wks}(n=5)$

$\triangle$ SHRSP.ZF 30 wks $(n=5)$ 